УДК 339.9

JEL classification: $F 42$

Макогон Ю.В.

доктор економ. наук, професор

Маріупольський державний університет

Заслужений діяч наук науки і техніки,

віце-президент Академія економічних наук України,

почесний професор Харбінського університету комериї (КНР)

ORCID ID: 0000-0002-3387-7031

\title{
СПІВРОБІТНИЦТВО УКРАЇНИ ТА КИТАЮ НА СУЧАСНОМУ ЕТАПI
}

\section{COOPERATION OF UKRAINE AND CHINA AT THE PRESENT STAGE}

У статті розглянуто аналіз українсько-китайського співробітництва на сучасному етапі. Проаналізовано розвиток спільної співпраці країн з різних напрямків: торговоекономічне, інвестиційне, соціально-культурне. Партнерство Украйни з Китаєм є одним з найважливіших стратегічних складових успішного економічного розвитку, в статті запропоновані можливі шляхи двосторонньої співпраці для отримання економічної вигоди у майбутньому. Зроблено огляд подій, які відбувались на шляху становлення та розвитку сучасних економічних зв'язків Китаю $i$ України, проаналізовано динаміку експортно-імпортних операцій України та КНР, наведені результати аналізу стану та зроблено висновки щуодо перспектив подальшого розвитку торговельних та інвестиційних відносин наших краӥн. Також окремо у статті відбувається огляд та аналіз обсягів поставок украӥнської агропродукиії в Китай. Проаналізовано товарні групи у структурі експорту китайських товарів в Украйну за останній рік. Окремо виділено пріоритетні напрямки двостороннього співробітництва України $і$ КНР в сфері науки $i$ техніки. У статті надано рекомендації щзодо найбільш перспективних напрямків діяльності китайських інвесторів в Україні та щуодо істотного збільшення припливу інвестицій з КНР. Детально проаналізовано аспекти сочіально-культурних відносин країн, особливо у сфері освіти, основні причини істотного збільшення туробміну, фактори подальшого розвитку двостороннього співробітництва в сфері освіти. У статті також було розглянуто насиченість китайсько-українськими культурними проектами, найважливішим з яких стало відкриття на півдні Пекіна музею-галереї видатного украӥнського поета і художника Тараса Шевченка. Розроблено пропозиціі щзодо пріоритетних напрямків розвитку співпращуі КНР $і$ України у різних сфрерах стосунків двох краӥн.

Ключові слова: Україно-китайське співробітництво, торгово-економічні відносини, інвестиції, стратегічний розвиток.

The article deals with the analysis of Ukrainian-Chinese cooperation at the present stage. The article analyses the development of joint cooperation of countries in different directions: trade and economic, investment, social and cultural. The partnership of Ukraine with China is one of the most important strategic components of successful economic development, the article suggests possible ways of bilateral cooperation in order to obtain economic benefits in the future. An overview of the events that took place on the way to the formation and development of modern economic ties between China and Ukraine was made, the dynamics of export-import operations of Ukraine and the PRC was analysed, the results of the state analysis were analysed 
and conclusions were drawn regarding prospects of further development of trade and investment relations of our countries. Also separately, the article reviews and analyses the volumes of supplies of Ukrainian agricultural products to China. The analysis of commodity groups in the structure of export of Chinese goods to Ukraine in the last year. Separately, the priority directions of bilateral cooperation between Ukraine and the People's Republic of China in the field of science and technology are singled out. The article gives recommendations on the most promising directions of activity of Chinese investors in Ukraine and a significant increase in investment inflows from the PRC. The aspects of socio-cultural relations of the countries, especially in the field of education, are analysed in detail, the main reasons for a substantial increase in labour exchange, factors of further development of bilateral cooperation in the field of education. The article also considered the saturation of the Sino-Ukrainian cultural projects, the most important of which was the discovery in the south of Beijing of the museum-gallery of the prominent Ukrainian poet and artist Taras Shevchenko. The proposals on priority directions of cooperation between the People's Republic of China and Ukraine in various spheres of relations between the two countries are elaborated.

Keywords: Ukrainian-Chinese cooperation, trade and economic relations, investments, strategic development.

Вступ. Сучасний стан зовнішньоекономічної діяльності України вимагає здійснення пошуку нових сегментів на світових ринках і перш за все на східно-азійському напрямку, де величезний ринок та джерела інвестицій. Крім того, на цьому ринку Україна має певні конкурентні переваги у відомих галузях промисловості та сільського господарства. Особлива значущість діяльності української економіки буде зростати найближчим часом та на перспективу у рамках нової парадигмі Китаю i світової спільноти відносно нового «Шовкового шляху» - один шлях один пояс.

Одна iз можливостей для економіки України це розвиток торговоекономічної співпраці 3 Китайською народною республікою не тільки у вже відомих напрямках та галузей, але i створення принципово нових, таких, наприклад, як IT-технологій, авіа-космічно, судобудівної галузей та інше.

Поряд $з$ суто економічними напрямками співпраці Україну та Китай об”єднає багато гуманітарних проектів, таких як освіта, наука, культура i Т.П.

Питання розвитку зовнішньоекономічного потенціалу України досить актуальне i вимагає від економічної науки більш ретельного вивчення та дослідження, у тому числі на теренах азійського континенту для якого територія нашої країни є транзитним шляхом до Свропи.

Постановка завдання. Метою даного наукового дослідження $\epsilon$ вивчення та аналіз економічного співробітництва України і Китаю, його майбутніх перспектив. Визначення основних векторів для подальшого розвитку даного партнерства.

Методологія. Дослідження здійснено 3 використанням економікоматематичного, розрахунково-аналітичного методів. Також у дослідженнях використовуються візуально-графічні методи для аналізу тенденцій 
поглиблення інтеграційних процесів щодо розвитку україно-китайських стосунків.

Результати дослідження. Стратегічно важливим партнером з моменту набуття незалежності України є КНР. Китай - країна, яка першою в грудні 1994 р. надала Україні гарантії ядерної безпеки у зв'язку з відмовою нашої країни від ядерної зброї. Визначальними для розвитку договірно-правової бази відносин $є$ Спільне комюніке про встановлення дипломатичних відносин між Україною і КНР, Спільна (Київська) декларація між Україною і КНР 1994 р., а також Спільна (Пекінська) декларація про розвиток та поглиблення відносин дружби і співробітництва між Україною та КНР 1995 p., що фактично виконує міжнародно-правову функцію міждержавного політичного договору.

Характерна ознака українсько-китайських відносин в політичній сфері високий рівень взаєморозуміння i довіри, відсутність принципових розбіжностей у зовнішньополітичних позиціях, тотожність або близькість підходів до вирішення важливих міжнародних проблем. Високий рівень розвитку двосторонніх зв'язків свідчать регулярні обміни візитами на високому та найвищому рівнях.

На одній $з$ останніх зустрічей уповноважених представників двох держав, яка відбулася на початку грудня 2017 року, Україна і Китай підписали дорожню карту з реалізації ініціатив "Економічний пояс Великого шовкового шляху" i "Морський шовковий шлях", покликаних посилити економічне співробітництво між Європою і Азією [6]. Ініціатива Китаю "Один пояс - один шлях" передбачає розвиток торговельних відносин між Китаєм і Європою. Посол КНР в Україні Ду Вей відзначав, що цей проект немислимий без України. Проекти в рамках "Шовкового шляху" в перспективі можуть дозволити Україні обійти транзитні обмеження Росії в країни Середньої Азії [6].

Україна i Китай надають важливого значення взаємодії в рамках міжнародних організацій, насамперед ООН. Існує чимало питань, згідно 3 якими позиції сторін близькі або збігаються: протидія гегемонізму i політичній силі в міжнародних відносинах; ядерне роззброєння; реформа системи ООН; боротьба з міжнародною злочинністю і тероризмом і т. ін. [2].

Посилення діалогу в політичній сфері, активна діяльність Міжурядової українсько-китайської комісії 3 питань торговельно-економічного співробітництва створили передумови для нарощування двосторонньої торгівлі, обсяги якої відрізняються рекордними, за сучасну історію двосторонніх зв'язків, показниками і динамікою зростання. Завдяки цьому Китай стабільно входить в десятку найбільших зовнішньоторговельних партнерів України і першої п'ятірки за обсягом споживання українського експорту. Для КНР Україна - третій зовнішньоторговельний партнер серед країн СНД.

Незважаючи на складне внутрішньо економічне становище країни: спад виробництва, зниження ВВП, низький рівень обсягів інвестицій, в т.ч. 
іноземних, значний розмір зовнішньої заборгованості і т.п., тим більше на тлі безперервного стійкого зростання економіки КНР, Україна докладає великі зусилля задля розвитку зовнішньоекономічних зв'язків з Китаєм.

Торговельно-економічне співробітництво.

Торговельно-економічне співробітництво між Україною i КНР регулюється Угодою між Урядом України і Урядом КНР про торговельноекономічне співробітництво від 1992 року, згідно з якою встановлено режим найбільшого сприяння з питань, які стосуються стягнення мита на експортні та імпортні товари обох країн, податків та інших внутрішніх зборів.

Впродовж останніх років в українсько-китайських торгових відносинах спостерігається істотне пожвавлення. За даними статистики, товарообіг між Україною і КНР за 12 місяців, наприклад, в 2008p. склав 8,660,858 тис. дол. США, що на 32,6\% більше, ніж за 12 місяців 2007p. За період 2012-2015pp. обсяг експортно-імпортних операцій між Україною і Китаєм мав тенденцію на спад, однак за останні роки ситуація значно покращилася. Імпорт товарів в Україну в 2017p. дорівнював 5,648,673,9 тис. дол. США, тобто на 40\% більше, ніж в 2015 р [4]. Експорт української продукції в Україну склав $2,039,327,6$ тис. дол. США - це на $80 \%$ більше показника ніж у 2008 року.

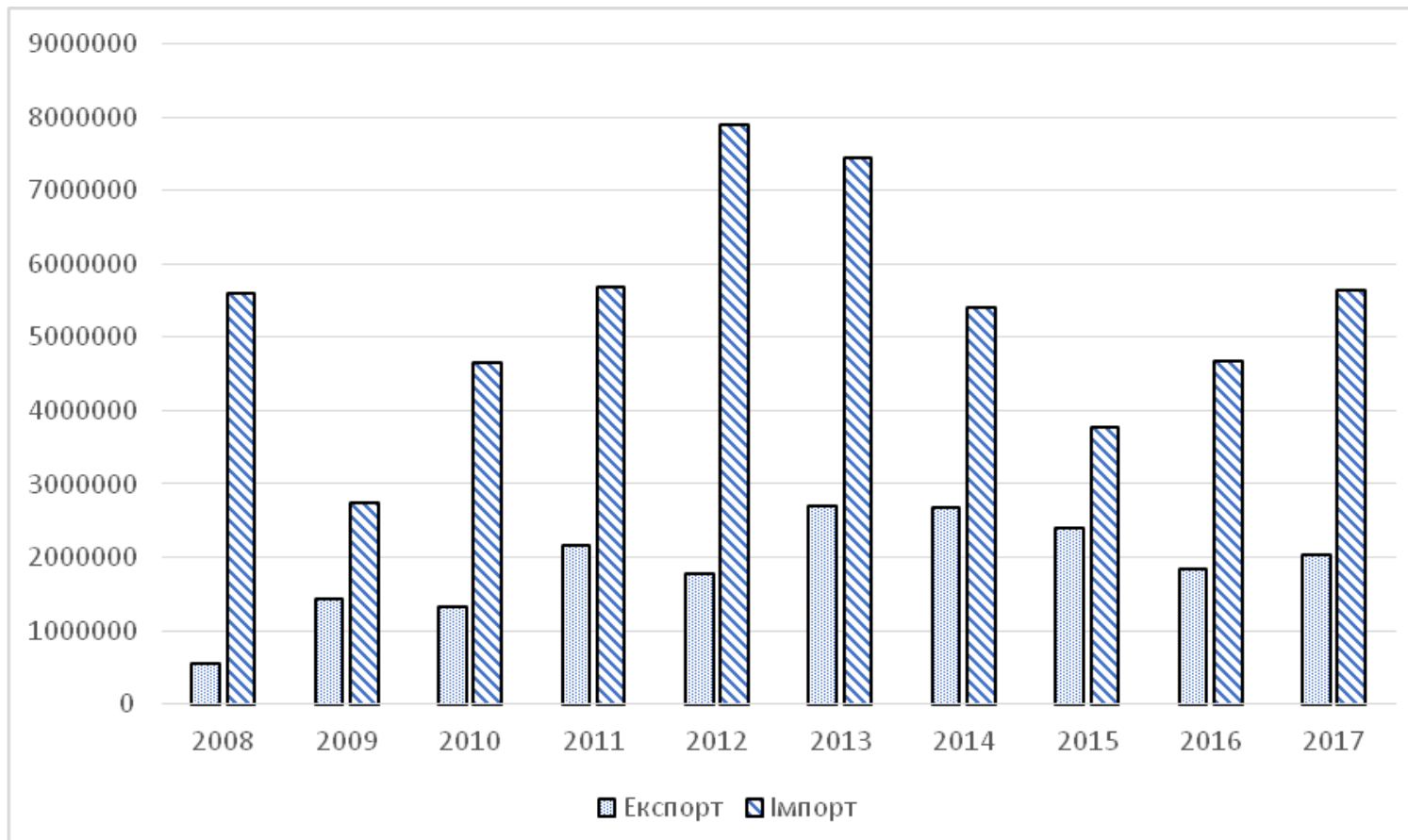

Рисунок 1 - Динаміка експортно-імпортних операцій України та КНР за 2008-2017pр., тис. дол. США Джерело: складено авторами на основі [4]

Слід зазначити, що в останні роки обсяг поставок української агропродукції в Китай зростає грандіозними темпами: з 2011 по 2015 рік він збільшився в 12 разів - 3103 млн. дол. США до 1,24 млрд. дол. США. При цьому Україна починає поступово відходити від експорту однієї лише сировини в користь готових продуктів харчування - сирів, йогуртів, 
кондитерських виробів, тобто товарів з високою доданою вартістю. Однак, незважаючи на всі ці позитивні тенденції, українські аграрії, за підрахунками Києва, поки використовують свій потенціал на китайському ринку лише на $7,5 \%[7]$.

У 2017 р. в структурі експорту китайських товарів в Україну переважали такі товарні групи: машини i механічні прилади, електрообладнання (35,53\%); текстиль та текстильні вироби (11,38\%) [4]; кольорові метали і вироби з кольорових металів (10,90\%); пластмаси та вироби з них $(7,93 \%)$; хімічна продукція $(7,33 \%)$; різні промислові вироби $(7,13 \%)$; взуття, головні убори, парасольки (4,86\%). Імпорт українських товарів в КНР був представлений такими групами: мінеральні продукти (42,57\%); продукти рослинного походження $(23,76 \%)$; тварини або рослинні жири і масла та продукти їх переробки (23,49\%) [4].

Відзначимо, що негативне сальдо в торгівлі з КНР мають більшість торгових партнерів Китаю, в тому числі найголовніші - США, СС, Південна Корея. Тільки одній країні 3 "великої сімки" притаманне перевищення власного експорту над імпортом з КНР - Японії.

Інвестииійна діяльність.

Російсько-китайське інвестиційне співробітництво поки що не відповідає можливостям Китаю i потребам України. Загальний обсяг інвестицій з КНР, за даними української статистики, становить приблизно 14 млн. дол. США. Одночасно, відповідно до затвердженого 11-м п'ятирічним планом (2006-2010 pp.) Стратегії державного курсу на інвестування китайського капіталу за кордон, китайський уряд надавало державну підтримку китайським компаніям i заохочував "вихід за кордон" їх капіталовкладень. Це створювало додаткові сприятливі умови для залучення китайських інвестицій в економіку України, зокрема в тих секторах, де китайська сторона бачить інтереси для розвитку i розширення своєї присутності, перш за все в реалізації проектів з видобутку вуглеводневих та інших не відновлюваних ресурсів, будівництва об'єктів інфраструктури (мостів, авто - і залізничних доріг, тунелів), житла та ін.

За даними української статистики, станом на 31.12.2017 р. В економіку України залучено 18,2 млн. дол. США інвестицій з Китаю. Найбільший обсяг інвестицій спрямований до підприємств в сфері сільського, лісового i рибного господарства, промисловості, оптової та роздрібної торгівлі; ремонту автотранспортних засобів і мотоциклів. Обсяг інвестицій з України в економіку Китаю склав 1,5 млн. дол.[5]. Основний обсяг цих інвестицій направлено на підприємства промисловості.

Пріоритетні напрямки двостороннього співробітництва України і КНР в сфері науки і техніки такі: ядерна енергетика; космічні дослідження; нові і високі технології; нафтогазова сфера; чорна металургія і т.д. Налагоджено ефективні механізми координації двостороннього науково-технічного співробітництва (в складі Міжурядової українсько-китайської Комісії 3 торговельно-економічного та науково-технічного співробітництва діють 
міжвідомчі Комісія 3 питань науково-технічного співробітництва та Підкомісія в області дослідження і використання космічного простору в мирних цілях).

Багато аналітиків також говорять про те, що в недалекому майбутньому одним з найбільш перспективних напрямків діяльності китайських інвесторів в Україні може стати відкриття в цій країні нових заводів. Крім ЗВТ з СС, важливою перевагою України $\epsilon$ також висококваліфікована і при цьому недорога робоча сила: через істотну девальвацію національної валюти мінімальна зарплата в цій країні зараз становить близько \$ 120 [7].

Тим часом, для істотного збільшення припливу інвестицій 3 КНР керівництву України необхідно послідовно покращувати внутрішній бізнесклімат, проводячи реформи, спрямовані на підтримку макроекономічної стабільності, боротьбу з корупцією і забезпечення незалежності судової влади. Тільки за таких умов іноземний капітал буде відчувати себе в Україні захищеним.

Соціально-культурне співробітництво.

Активно розвивається співпраця між Україною і КНР в галузі освіти. Серед китайських громадян значно зросла зацікавленість в отриманні вищої освіти в Україні. Встановлено прямі контакти між багатьма вищими навчальними закладами України та КНР (35 українських університетів підтримують прямі зв'язки з 98 вищими навчальними закладами та науководослідними інститутами Китаю). Серед них і Маріупольський державний університет і Харбінський університет комерції, які уклали відповідну угоду, реалізація якого, дозволяє удосконалювати і розвивати навчальний процес, наукові дослідження, активізувати видавничо-публікаційну діяльність, проводити міжнародні науково-практичні конференції в області розвитку зовнішньоекономічних зв'язків України і Китаю.

У вищих навчальних закладах України навчаються майже 10 тис. китайських студентів. Триває практика обміну студентами на міждержавному рівні. В рамках реалізації Угоди про співробітництво між міністерствами освіти України і КНР з 1999 р. збільшена квота обміну студентами та аспірантами з 20 до 25 осіб.

Підтримуються зв'язки з вищими навчальними закладами КНР, в яких відкриті кафедри української мови. Це, зокрема, Пекінський інститут іноземних мов i Шанхайський інститут міжнародних відносин. При Уханьському університеті діє Центр українознавства. На той період співробітники Центру вже написали більше 50 дисертацій 3 питань, пов'язаних з українською тематикою. В університеті впроваджена програма вивчення української мови, створені відповідні методичні посібники.

Представники українських вищих закладів освіти регулярно беруть участь в традиційних освітніх виставках, які двічі на рік проходять в КНР (зазвичай в березні і жовтні).

3 робочими візитами в Китаї перебували керівники Київського національного університету ім. Т. Шевченка, Київського національного 
технічного університету України "КПІ", Дніпропетровського національного університету, Національної музичної академії України, Національної академії металургії, Національного фармацевтичного університету, Харківського авіаційного університету, Київського національного авіаційного університету, Харківського національного технічного університету "ХПІ", Київського національного транспортного університету, Івано-Франківського національного технічного університету нафти і газу, Сумського державного університету та ін.

Подальшому розвитку двостороннього співробітництва в сфері освіти та спорту сприяла участь українських студентів у XXIV Всесвітній зимовій універсіаді, яка відбулася в м. Харбін 18-28 лютого 2009 р. Збірна студентська команда України була представлена в десяти видах програми. У змаганнях взяли участь 71 спортсмен і 21 тренер з 11 регіонів нашої країни, які представляли 24 вищих навчальних закладів. Українські спортсмени успішно виступили на зимовій Універсіаді, завоювали 7 медалей різного гатунку і зайняли 13-е загальнокомандне місце серед 44 країн світу.

Крім нарощування китайсько-українського торгово-економічного та інвестиційного співробітництва, 2016 рік ознаменувався також розвитком туризму: за попередніми даними, в минулому році Україну відвідали близько 25 тисяч китайських туристів, що в два рази більше, ніж роком раніше.

Основною причиною такого істотного збільшення туробміну послужила стабілізація ситуації в Україні, в тому числі, в її східних областях. Однак був і інший фактор, Україна зробила помітні кроки в бік лібералізації візового режиму для китайських громадян. Зокрема, з 20 червня 2016 року в київському аеропорту «Бориспіль», а $з 1$ жовтня - ще й в аеропорту «Одеса» (Одеса, Південна Україна) діє спрощений порядок в'їзду на українську територію для китайських бізнесменів і туристів. Він передбачає оформлення віз терміном до 15 днів після прибуття в один з двох зазначених повітряних портів.

2016 рік був також вельми насичений китайсько-українськими культурними проектами, найважливішим з яких стало відкриття на півдні Пекіна музею-галереї видатного українського поета і художника Тараса Шевченка. Цей музей буде використовуватися як майданчик для постійної експозиції, а також тимчасових виставок, які знайомлять 3 роботами сучасних китайських і українських художників, скульпторів і фотографів [7].

Для збільшення кількості подібних спільних проектів восени минулого року КНР відвідала українська делегація на чолі 3 міністром культури України Свгеном Нищуком. В ході переговорів Нищука з його китайським колегою Ло Шуганом було обговорено широке коло питань, серед яких: створення в КНР українських культурних центрів, шляхи взаємного просування прикладних народних ремесел, проведення концертів за участю артистів з обох країн тощо [7].

У минулому році Китай також приділяв чимало уваги надання Україні матеріально-технічної допомоги в сфері освіти. Зокрема, він передав 
українським школам 23,5 тисячі нових комп'ютерів і обладнав три лінгафонні кабінети в Київській гімназії східних мов №1, де китайську мову вивчає близько 600 дітей. Крім цього, Міжнародна торгова палата «Шовкового шляху» виділила Україні 200 тисяч дол. США на освітні проекти для школярів з особливими потребами [7].

Висновки. Вивчивши і проаналізувавши статистичну інформацію про співпрацю України і Китаю, можна однозначно позначити, що на даному етапі розвитку для української економіки вкрай необхідна підтримка азіатського регіону. Китай, залишаючись світовим лідером 3 однією 3 провідних економік, надає величезну підтримку Україні на даному етапі і $\epsilon$ найважливішим торговим партнером.

Bсе це свідчить про те, що Китай зацікавлений в безперервному розвитку України, а також подальше зміцнення двостороннього співробітництва на взаємовигідній основі. Україна, в свою чергу, слід займати ще більш активну позицію в просуванні міждержавної взаємодії для знаходження нових точок дотику.

Основним шляхом розвитку України має залишатися вдосконалення торгової політики для зміцнення економічного співробітництва 3 країнами світу, перш за все на азійському напрямку, а також впровадження цільових програм і проектів для відновлення економік регіонів України.

\section{Література:}

1. Makogon Y. Socio-economic consequences of the political and military confrontation in Southeast Ukraine North/ East Asia Academic Forum (Publication of scientific articles). Chine: Harbin University of Commerce, 2016. 06. C.9-15

2. Асоціація

українсько-китайського

співробітництва

URL: http://aucc.org.ua/uk/

3. Макогон Ю. В., Курбала Н. В. Основные тенденции развития, причины и факторы экономического кризиса в Украине в условиях военно-политического кризиса на востоке страны в 2014 - 2015 гг. North - East Asia Academic Forum (Publication of scientific articles). Chine: Harbin University of Commerce, 2017. No 1. P. 64-77.

4. Офіційний сайт державного комітету статистики України URL: http://www.ukrstat.gov.ua

5. Офіційний сайт Конференції ОOH 3 торгівлі та розвитку URL: https://unctad.org/en/Pages/statistics.aspx

6. УНIAH Інформаційне агентство. URL: https://www.unian.ua/economics/finance/10330014-ukrajina-zaproponuvala-kitayu-pochatikonsultaciji-pro-stvorennya-zoni-vilnoji-torgivli.html

7. Китайсько-українські відносини на сьогоднішньому етапі (огляд «Сіньхуа»). China Radio International. CRI. URL: http://ukrainian.cri.cn/841/2017/02/04/2s47635.htm 